\title{
RANCANGAN PENDAMPINGAN "4 SKILLS OF RESILIENCE” UNTUK PENGEMBANGAN RESILIENSI BIDANG AKADEMIK PADA MAHASISWA BIDIK MISI
}

\author{
Miryam Wedyaswari, Surya Cahyadi, Erna Susiati, dan Rasni Adha Yuanita \\ Fakultas Psikologi, Universitas Padjadjaran, \\ Jl. Raya Bandung-Sumedang KM.21 Jatinangor, Sumedang, Jawa Barat, \\ E-mail: m.wedyaswari@unpad.ac.id
}

Diserahkan 07 Maret 2019; Diterima 19 Juli 2019; Dipublikasikan 01 Agustus 2019

\begin{abstract}
ABSTRAK
Mahasiswa bidik misi tergolong ke dalam students at risk - siswa dengan risiko gagal lebih tinggi daripada siswa lainnya. Mereka berasal dari golongan status sosial ekonomi menengah ke bawah dengan tuntutan wajib lulus 4 tahun, minimal IPK 2.5, dan ancaman dicabut beasiswa jika semua hal itu tidak terpenuhi. Untuk itulah kemampuan resiliensi diperlukan. Tujuan penelitian ini yaitu untuk membuat rancangan pendampingan 4 skills of resilience yang sesuai untuk mengembangkan kemampuan resiliensi mereka. Penelitian ini menggunakan definisi resiliensi dari Reivich-Shatte (2002). Pendampingan dirancang untuk mahasiswa bidik misi Fakultas Psikologi Universitas Padjadjaran tingkat ketiga sebagai upaya antisipasi mereka menghadapi evaluasi akhir dari DIKTI. Berdasarkan analisis kebutuhan, sebagian besar mahasiswa bidik misi tingkat ketiga memiliki kemampuan resiliensi cenderung rendah terutama pada faktor impuls control, causal analysis, dan realistic optimism. Teknik purposive sampling digunakan untuk memilih partisipan yang sesuai dengan kriteria peneliti sehingga didapatkanlah 3 partisipan. Empat keterampilan resiliensi yaitu Learning your ABC, Avoiding thinking traps, Challenging belief, dan Putting it in perspective akan dilatihkan untuk meningkatkan ketiga faktor yang rendah tersebut. Pendampingan ini dirancang dalam 6 sesi. Metode penelitian yang digunakan adalah Mixed Method: triangulation embedded design. Hasil dari penelitian ini menunjukkan bahwa rancangan pendampingan untuk sesi I dan sesi II sudah sesuai untuk meningkatkan keterampilan resiliensi pada faktor Impuls Control. Sedangkan sesi III dan IV belum sesuai untuk meningkatkan keterampilan resiliensi (faktor Causal Analysis dan Realistic Optimism) sehingga dibutuhkan perbaikan pada konten dan prosedur rancangan.
\end{abstract}

Kata kunci: Resiliensi; Bidang Akademik; Psikologi Positif; Mahasiswa Bidik Misi; Rancangan Pendampingan

\section{DESIGNING COACHING PROGRAM “4 SKILLS OF RESILIENCE” TO IMPROVE BIDIK MISI STUDENTS' IN ACADEMIC CONTEXT}

\begin{abstract}
Bidik Misi students are categorized as student at risk. They have higher risk for failure than other students. Most of bidik misi students came from low social economic status. As compensation from scholarship gotten from DIKTI, they have to finish their study in 4 years with minimal GPA 2.5 and will get a warning to drop their scholarship if those condition didn't meet. For striving those conditions, bidik misi students may need resilience. This study aims to create coaching: "4 Skills of Resilience". Resilience theory from Reivich-Shatte (2002) was used in this study. The coaching was designed for third year-bidik misi students, Faculty of Psychology, Universitas Padjadjaran. Based on need assessment, most of them have low level of resilience, especially in these three factors: impulse control, causal analysis, and realistic optimism. Purposive sampling was used to choose participant based on characteristics determined by researcher $(n=3)$. For resilience skillthe following were given: Learning your ABC, Avoiding thinking traps, Challenging belief, and Putting it in perspective to improve deficient resilience factor for 6 session. Mixed Method: triangulation embedded design was used to investigate the effectivity of coaching program. This study show that Session I and Session II could improve resilience in Impulse Control factor. While Session III could not improve Causal Analysis factor and Session IV could not improve Realistic Optimism factor. Coaching design for session III and IV should be revised in content and procedure.
\end{abstract}

Keywords: Resilience; Academic Context; Positive Psychology; Bidik Misi Students; Coaching Design

Rancangan Pendampingan “4 Skills Of Resilience” untuk Pengembangan Resiliensi Bidang Akademik pada Mahasiswa Bidik Misi 


\section{PENDAHULUAN}

Bidik misi adalah program bantuan biaya pendidikan bagi calon mahasiswa tidak mampu secara ekonomi dan memiliki potensi akademik baik untuk menempuh pendidikan di perguruan tinggi pada program studi unggulan sampai lulus tepat waktu (Direktorat Jenderal Pendidikan tinggi, 2010). Mahasiswa bidik misi memilliki tantangan yang lebih banyak dibandingkan mahasiswa biasa pada umumnya. Mahasiswa bidik misi berasal dari keluarga berlatar belakang ekonomi dan sosial yang kurang menguntungkan. Di samping itu, mahasiswa bidik misi dituntut untuk berprestasi di bidang akademik (sekurang-kurangnya IPK 2,75) dan juga di bidang non akademik (setidaknya mengikuti organisasi dan/kepanitiaan).

Tantangan dan tuntutan terhadap mahasiswa bidik misi ini menjadi masalah dan sumber stres bagi mahasiswa bidik misi. Robotham (2008 dalam Calaguas, 2012) menemukan bahwa peserta didik akan mengalami peningkatan stres ketika menjadi mahasiswa. Hussain, Kumar, dan Husain (2008) menyimpulkan bahwa stres ini tidak hanya mempengaruhi performa akdemik tetapi juga berpengaruh pada aspek yang lebih luas seperti penyesuaian diri. Selain itu, berasal dari latar belakang keluarga yang kurang menguntungkan, lingkungan sosial yang amat berbeda dengan tempat asal, menjadi kondisi ini menambah beban pikiran dan emosi mahasiswa bidik misi. Dengan kata lain, apabila mahasiswa tidak dapat menyiasati kesulitan dan tantangan yang dia alami, risiko mahasiswa tersebut untuk gagal di perguruan tinggi akan meningkat (high risk of academic failure).

Menjadi mahasiswa yang resilien (resilient student) adalah salah satu cara untuk menghindari risiko kegagalan di perguruan tinggi (Martin \& Marsh, 2003; Goodwin, 2002; Masten, 2001). Resiliensi adalah kemampuan untuk menghadapi situasi yang sulit. Resiliensi dibutuhkan oleh setiap individu karena tentunya setiap manusia akan mengalami permasalahan/kesulitan dalam menjalani kehidupan. Semakin tinggi tingkat resiliensi seseorang, semakin mampu dia menghadapi berbagai kesulitan yang dialami secara efektif dan bagaimana cara kita berpikir, keakuratan cara berpikir kita dalam menghadapi kesulitan menjadi kunci dari kemampuan resiliensi (Reivich-Shatte, 2002). Penelitian mengenai resiliensi di bidang pendidikan sendiri berfokus pada bagaimana agar students at risk of academic failure dapat sukses. Dari sejumlah penelitian yang dilakukan, resiliensi telah diakui sebagai kerangka pemikiran yang terbukti secara konsep dan empiris membantu siswa untuk meraih kesuksesan tersebut .(Review of Research on Educational Resilience diunduh dari www.cal.org/aede/pdfs/rr11.pdf)

Konsep resiliensi yang dikemukakan oleh Reivich dan Shatte telah digunakan oleh beberapa peneliti di dalam dunia pendidikan. Hyland (2009) mengulas dan mempublikasikan mengenai pengembangan resiliensi untuk meraih pencapaian prestasi akademik yang lebih tinggi pada pelajar di Geelong Grammar School, Australia. Konsep resiliensi ini digunakan juga dalam pendidikan untuk anak-anak yang disebut dengan program "RIRO (Reaching In, Reaching Out)" yang dikembangkan oleh Jennifer Pedson \& Darlene Kordich Hall, R. N. Ph.D sejak tahun 2006. Konsep ini pun digunakan sebagai program preventif terhadap depresi pada siswa sekolah dasar (Gillham, Gallop, Reivich, Seligman, \& Shatte, 2007). Terdapat juga program "Building Resilience in Young People" yaitu program pengembangan resiliensi melalui aktivitas di kelas dalam sekolah (Reach Out Teachers Network, 2012). Namun memang belum ada yang spesifik pada area students at risk dalam bidang akademik sehingga semakin penting untuk diteliti.

Untuk bisa menjadi individu yang resilien, mahasiswa harus dapat mengidentifikasi sejauh manakah kemampuan resiliensi yang dimiliki. Kemampuan resiliensi ini dapat diidentifikasi dengan mengetahui profil kekuatan internal manusia. Karen Reivich dan Andrew Shatte (2002) menjelaskan bahwa terdapat 7 (tujuh) faktor penting yang merupakan kekuatan internal manusia yang berpengaruh terhadap kemampuan resiliensi seseorang. Ketujuh faktor tersebut adalah emotional awareness \& regulation; impuls control; causal analysis; realistic optimism; empathy; self-efficacy; dan reaching out. Setiap mahasiswa akan memiliki profil resiliensi yang berbeda-beda, tergantung dari komposisi tujuh faktor tersebut.

Reivich danShatte (2002) menjelaskan bahwa cara untuk mengembangkan resiliensi adalah memahami gaya berpikir kita, cara bagaimana kita melihat dan menginterpretasi diri sendiri serta kejadian-kejadian yang terjadi di sekitar kita. Dari kunci dasar pengembangan resiliensi ini, Reivich-Shatte mengembangkan 7 skills of resilience yang dapat digunakan untuk mengembangkan resiliensi seseorang.

Berdasarkan hasil analisis kebutuhan terhadap mahasiswa bidik misi angkatan 2013 fakultas Psikologi Universitas Padjadjaran (UNPAD), ditemukan bahwa lebih dari setengah jumlah mahassiswa bidik misi memiliki kemampuan resiliensi yang cenderung rendah. Terdapat 3 (tiga) faktor yang tergolong rendah pada hampir semua mahasiswa bidik misi yaitu impuls control, causal analysis, dan realistic optimism. Data ini memperkuat faktor risiko mahasiswa bidik misi untuk mengalami kegagaalan dalam situasi akademik. Agar mahasiswa bidik misi ini dapat terhindar dari golongan 
students at risk of academic failure, kemampuan resiliensi mereka perlu dikembangkan.

Selain fenomena tersebut, konsep Resiliensi dari Reivich-Shatte memang pernah dilakukan oleh beberapa peneliti di bidang akademik, namun belum ada yang secara spesifik mengarah pada students at risk of academic failure seperti mahasiswa bidik misi. Oleh karena itu, peneliti tertarik untuk membuat sebuah pelatihan individual (coaching/pendampingan) sebagai intervensi untuk mengembangkan resiliensi. Modul pendampingan akan dirancang menggunakan konsep resiliensi dari Reivich dan Shatte (2002). Adapun pengembangan resiliensi akan dilakukan dengan memberikan 4 dari 7 skills of resilience, yaitu learn your $A B C$, avoiding thinking trap, challenging beliefs, dan putting it in perspective.

Pertanyaan penelitian ini adalah apakah rancangan pendampingan sudah sesuai untuk melatihkan 4 skill of resilience ? Implementasi rancangan pendampingan dan evaluasinya akan menjadi bukti empiris untuk menjawab pertanyaan tersebut. Adapun hipotesis penelitian dari penelitian ini adalah sebagai berikut:

(1) Rancangan pendampingan yang disusun sudah sesuai untuk melatihkan Learning your ABC skill \& Avoiding thinking traps skill sebagai sarana untuk meningkatkan faktor impuls control; (2) Rancangan pendampingan yang disusun sudah sesuai untuk melatihkan Learning your ABC skill \& Challenging Beliefs skill sebagai sarana untuk meningkatkan faktor causal analysis; dan (3) Rancangan pendampingan yang disusun sudah sesuai untuk melatihkan Putting it in perspectives skill sebagai sarana untuk meningkatkan faktor realistic optimism.

\section{METODE}

\section{Rancangan Penelitian}

Rancangan penelitian yang digunakan adalah triangulation embedded mixed design. Peneliti menggunakan rancangan penelitian kuantitatif untuk mengukur resiliensi sebelum dan setelah pelatihan. Selama proses pelatihan, data kualitatif akan dikumpulkan melalui wawancara dan observasi. Berikut adalah bagan yang menggambarkan rancangan penelitian:

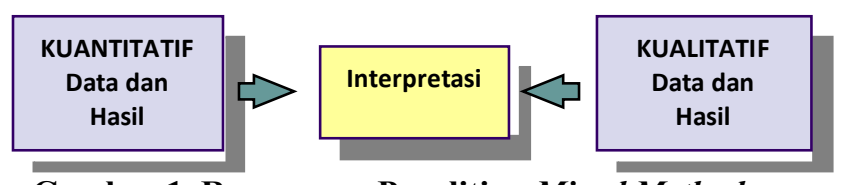

Gambar 1. Rancangan Penelitian Mixed Method

Rancangan penelitian kuantitatif yang digunakan adalah Non experimental design: One
Group Pretest-Posttest Design. Tes untuk mengukur resiliensi diberikan sebelum dan sesudah pendampingan pada kelompok penelitian. Perbedaan skor pada masing-masing partisipan diuji perbedaannya sehingga dapat disimpulkan terdapat peningkatan resiliensi atau tidak pada partisipan.

Rancangan penelitian kualitatif yang digunakan adalah collective case study. Pada penelitian ini, peneliti memilih satu isu yaitu resiliensi mahasiswa bidik misi di fakultas Psikologi UNPAD, kemudian peneliti mencari berbagai kasus terkait isu tersebut. Beberapa kasus ini antara lain adalah lebih dari satu mahasiswa bidik misi yang mengikuti pendampingan 4 skills of resilience. Pada setiap kasusnya, akan diterapkan prosedur penelitian yang sama, replika dari metode penelitian yang peneliti rancang (Yin, 2003 dalam Creswell, 2007). Setelah pengambilan data penelitian ini, setiap kasusnya akan dideskripsikan dengan detail termasuk tema-tema resiliensi yang ada di dalamnya (within case analysis); barulah setelah itu akan dilakukan analisis tema antar kasus (cross case analysis) (Creswell, 2007).

\section{Rancangan Pendampingan}

Pendampingan ini merupakan pelatihan individual. Setiap partisipan melalui 6 sesi pendampingan dengan durasi setiap sesi kurang lebih 45 - 60 menit. Dalam setiap pertemuan, partisipan diberikan beberapa sesi sehingga pada umumnya partisipan melalui sesi pengantar, I, \& II pada pertemuan pertama; sesi III, IV, \& V pada pertemuan kedua; dan sesi VI pada pertemuan ketiga. Pertemuan kedua dilaksanakan keesokan harinya pertemuan pertama. Sedangkan pertemuan ketiga dilaksanakan 1 minggu setelah pertemuan kedua.

Tabel 1. Gambaran Rancangan Pendampingan

\begin{tabular}{|c|c|c|}
\hline Nama Sesi & Tujuan & Keterangan \\
\hline $\begin{array}{l}\text { Sesi I: } \\
\text { Yuk Kita } \\
\text { Kenali } \\
\text { Bagaimana } \\
\text { Cara Kita } \\
\text { Berpikir! }\end{array}$ & $\begin{array}{l}\text { Peserta mampu mengenali } \\
\text { bagaimana cara dia berpikir } \\
\text { dalam menhgadapi } \\
\text { tantangan/permasalahan } \\
\text { akademik }\end{array}$ & $\begin{array}{l}\text { Diawali dengan } \\
\text { sesi pengantar } \\
\text { dan dilakukan } \\
\text { pada Pertemuan } \\
\text { Pertama }\end{array}$ \\
\hline $\begin{array}{l}\text { Sesi II: Lets } \\
\text { Avoid } \\
\text { Thinking } \\
\text { Traps! }\end{array}$ & $\begin{array}{l}\text { Peserta mampu menentukan } \\
\text { self-questioning untuk } \\
\text { menghambat thinking trap } \\
\text { yang sering kali muncul } \\
\text { saat menghadapi suatu } \\
\text { tantangan/permasalahan } \\
\text { akademik }\end{array}$ & $\begin{array}{l}\text { Pertemuan } \\
\text { Pertama }\end{array}$ \\
\hline $\begin{array}{l}\text { Sesi III: Lets } \\
\text { Think More } \\
\text { Accurate And } \\
\text { Flexible! }\end{array}$ & $\begin{array}{l}\text { Peserta } r \text { mampu } \\
\text { mendemonstrasikan } \\
\text { bagaimana cara untuk } \\
\text { mengubah pemikirannya } \\
\text { mengenai penyebab suatu } \\
\text { permasalahan (why belief) }\end{array}$ & $\begin{array}{l}\text { Pertemuan } \\
\text { Kedua }\end{array}$ \\
\hline
\end{tabular}




\begin{tabular}{|c|c|c|}
\hline & menjadi lebih akurat & \\
\hline $\begin{array}{l}\text { Sesi IV: Lets } \\
\text { Predict Impact } \\
\text { More } \\
\text { Realistic! }\end{array}$ & $\begin{array}{l}\text { Peserta mampu } \\
\text { mendemonstrasikan } \\
\text { bagaimana cara mengubah } \\
\text { pemikirannya mengenai } \\
\text { output di masa depan (what } \\
\text { next belief) menjadi lebih } \\
\text { realistis }\end{array}$ & $\begin{array}{l}\text { Pertemuan } \\
\text { Kedua }\end{array}$ \\
\hline $\begin{array}{l}\text { Sesi V: Make } \\
\text { Your Action } \\
\text { Plan }\end{array}$ & $\begin{array}{l}\text { Peserta dapat menentukan } \\
\text { kegiatan dan dapat } \\
\text { memrediksi hambatan apa } \\
\text { yang akan dia hadapi dan } \\
\text { bagaimana } \\
\text { mengantisipasinya }\end{array}$ & $\begin{array}{l}\text { Pertemuan } \\
\text { Kedua }\end{array}$ \\
\hline $\begin{array}{l}\text { Sesi VI: } \\
\text { Follow Up }\end{array}$ & $\begin{array}{l}\text { Peserta mengetahui manfaat } \\
\text { dari cara keempat } \\
\text { keterampilan tersebut } \\
\text { dan mengetahui hambatan } \\
\text { apa saja yang mungkin } \\
\text { terjadi dalam memanfaatkan } \\
\text { keterampilan tersebut }\end{array}$ & $\begin{array}{l}\text { Pertemuan } \\
\text { Ketiga } \\
(1 \quad \text { minggu } \\
\text { setelah } \\
\text { pertemuan } \\
\text { kedua) }\end{array}$ \\
\hline
\end{tabular}

\section{Partisipan Penelitian}

Populasi dari penelitian ini adalah mahasiswa bidik misi fakultas Psikologi Universitas Padjadjaran mulai dari semester lima. Penelitian ini menggunakan teknik pengambilan sampel non probabilistic sampling, yaitu pada saat pemilihan sampling tidak melibatkan faktor peluang. Salah satu teknik dari non probabillistic sampling adalah purposive sampling, yaitu sampel diambil berdasarkan pada tujuan tertentu yang ingin dicapai oleh peneliti. Adapun karakteristik partisipan pada penelitian ini adalah: (1)Mahasiswa bidik misi Angkatan 2013 Fakultas Psikologi Universitas Padjadjaran; (2) Memiliki IPK Kurang dari sama dengan 2.75;(3) Memiliki kemampuan resiliensi yang tergolong cukup rendah dan rendah; serta (4) Memiliki profil yang rendah pada faktor Impuls control, Causal Analysis, dan Realistic Optimism.

\section{Alat Ukur Penelitian}

Penelitian ini menggunakan 3 alat ukur. Alat ukur pertama adalah Kuesioner Resiliensi (RQ Test) yng diadaptasi dari konsep resiliensinya ReivichShatte. Kuesioner ini menggunakan skala Likert dengan pilihan jawaban bergerak dari 1 (sangat tidak setuju) sampai 6 (sangat setuju) sebanyak 54 item $(r$ $=.88$ ).

Alat ukur kedua adalah panduan observasi: skenario pendampingan. Panduan observasi ini diberikan kepada 2 (dua) orang rater. Rater akan melakukan observasi melalui video rekaman pendampingan. Rater akan mengamati 3 (tiga) hal yaitu kesesuaian instruksi dengan rancangan, bagaimana respon yang muncul dari partisipan, dan tercapai atau tidaknya indiktor keberhasilan (Panduan observasi terlampir).
Alat ukur ketiga adalah Panduan Wawancara: Follow Up Action Plan. Panduan wawancara ini selain dilakukan untuk melihat sejauh mana partisipan melakukan apa yang mereka rencanakan, juga disusun untuk mengetahui apakah partisipan mengaplikasikan keempat keterampilan itu dalam menghadapi permasalahan yang muncul selama menjalani action plan. Dengan kata lain, panduan wawancara ini untuk mengukur level penguasaan partisipan mengenai keempat keterampilan resiliensi, sebagai hasil dari rancangan pendampingan yang telah dilakukan (Panduan wawancara terlampir).

\section{Analisis Data}

Evaluasi kesesuaian rancangan pendampingan untuk pengembangan resiliensi mahasiswa bidik misi akan ditinjau dari 1 (satu) level dengan 3 (tiga) sumber data yaitu level program proses, dari sumber data (1) pendamping beserta tim interrater; (2) coachees; dan (3) dokumen.

Berdasarkan rancangan penelitian yang digunakan, analisis data dilakukan secara kuantitatif maupun kualitatif. Untuk pendekatan kuantitatif digunakan analisa non parametrik sebagai metode yang berlaku untuk data yang berdistribusi bebas, salah satunya adalah data yang tidak berdistribusi normal (Sudjana, 2005). Statistik nonparametrik juga dapat digunakan untuk extremly small samples dengan catatan populasinya dapat digambarkan secara detail (Siegel, 1956). Kemudian digunakanlah Uji Tanda Wilcoxon untuk menguji perbedaan nilai tengah (median) pada dua populasi yang berpasangan.

$$
\begin{gathered}
\mathrm{H}_{0}: \mathrm{m}_{\text {pre }}=\mathrm{m}_{\text {post }} \\
\mathrm{H}_{1}: \mathrm{m}_{\text {pre }}>\mathrm{m}_{\text {post }} \\
\mathrm{m}_{\text {pre }}=\text { median skor pretest Resiliensi/faktor } \\
\text { tertentu } \\
\mathrm{m}_{\text {post }}=\text { median skor posttest Resiliensi/faktor } \\
\text { tertentu }
\end{gathered}
$$

Hipotesis nol ditolak jika $\alpha$ (taraf signifikansi) $<$ 0.05 yang bermakna terdapat peningkatan resiliensi partisipan setelah dilakukan pendampingan.

Sedangkan untuk analisis data kualitatif dilakukan untuk membahas proses pendampingan yang terjadi dengan menggunakan teknik data analysis spiral (Cresswell, 2007). Terdapat 4 (empat) lompatan (loop) dalam data analysis spiral ini. Loop pertama adalah manajemen data sebagai proses awal dalam menganalisis. Dalam tahap ini, peneliti menuliskan transkip wawancara antara peneliti dan partisipan. Loop kedua adalah reading \& memoing. Pada tahap ini peneliti membaca kembali jawaban partisipan dan menggaris bawahi pernyataan yang menggambarkan faktor resiliensi tertentu. Loop ketiga adalah describing, classifying, \& interpreting. 
Pada tahap ini peneliti menggambarkan kembali pernyataan yang digaris bawahi tersebut dan menginterpretasikan bagaimana aspek tertentu pada partisipan berdasarkan pernyataan-pernyataan yang telah digarisbawahi. Ada pun panduan interprentasinya berupa coding yang menguraikan tercapai atau tidaknya, sesuai atau tidaknya suatu aspek. Loop yang terakhir adalah representing, peneliti menguraikan hasil analisis dari uji coba rancangan program. Berikut adalah panduan analisis untuk alat ukur wawancara \& observasi:

Tabel 2. Panduan Analisis Kualitatif

\begin{tabular}{|c|c|c|}
\hline $\begin{array}{c}\text { Skills of } \\
\text { Resilience }\end{array}$ & $\begin{array}{c}\begin{array}{c}\text { Indikator Penguasaan } \\
\text { Keterampilan }\end{array} \\
\end{array}$ & $\begin{array}{r}\text { Data yang } \\
\text { Digunakan }\end{array}$ \\
\hline \multirow{4}{*}{$\begin{array}{l}\text { Skill 1: } \\
\text { Learning } \\
\text { Your } A B C\end{array}$} & $\begin{array}{l}0=\text { partisipan belum mengetahui } \\
\text { keterampilan yang diberikan }\end{array}$ & \multirow{4}{*}{$\begin{array}{l}\text { Jawaban } \\
\text { partisipan } \\
\text { terhadap } \\
\text { semua } \\
\text { Pertanyaan: } \\
\text { Khusus 1 \& } \\
\text { Observasi } \\
\text { Sesi } 1\end{array}$} \\
\hline & $\begin{array}{l}1=\text { Partisipan mampu } \\
\text { menyatakan dan menyebutkan } \\
\text { kembali apa itu } \mathrm{ABC}\end{array}$ & \\
\hline & $\begin{array}{l}2 \quad=\text { Partisipan mampu } \\
\text { menguraikan sendiri ABC dari } \\
\text { setiap permasalahan yang sedang } \\
\text { dibahas }\end{array}$ & \\
\hline & $\begin{array}{l}3=\text { Partisipan mampu } \\
\text { menguraikan pada situasi seperti } \\
\text { apa keterampilan ABC bisa } \\
\text { diterapkan dan menerapkannya } \\
\text { pada situasi tersebut. }\end{array}$ & \\
\hline \multirow{4}{*}{$\begin{array}{l}\text { Skill 2: } \\
\text { Avoiding } \\
\text { Thinking } \\
\text { Traps }\end{array}$} & $\begin{array}{l}0=\text { partisipan belum mengetahui } \\
\text { keterampilan yang diberikan }\end{array}$ & \multirow{4}{*}{$\begin{array}{l}\text { Jawaban } \\
\text { partisipan } \\
\text { terhadap } \\
\text { semua } \\
\text { Pertanyaan: } \\
\text { Khusus 2 \& } \\
\text { Observasi } \\
\text { Sesi } 2\end{array}$} \\
\hline & $\begin{array}{l}1=\text { Partisipan menyebutkan } \\
\text { kembali apa itu thinking traps dan } \\
\text { bagaimana cara menghindarinya }\end{array}$ & \\
\hline & $\begin{array}{l}2 \text { = Partisipan mampu } \\
\text { mengategorikan belief yang } \\
\text { muncul ke dalam jenis thinking } \\
\text { traps dan mampu menuliskan } \\
\text { satu self-question pada setiap } \\
\text { thinking traps yang muncul }\end{array}$ & \\
\hline & $\begin{array}{lrr}3= & \text { Partisipan } & \text { mampu } \\
\text { menguraikan apa } & \text { manfaat } & \text { dari } \\
\text { keterampilan } & 2 & \text { dan } \\
\text { menggunakannya } & \text { untuk } \\
\text { mengatasi permasalahan } & \text { sehari- } \\
\text { hari } & \\
\end{array}$ & \\
\hline \multirow{4}{*}{$\begin{array}{l}\text { Skill 3: } \\
\text { Challenging } \\
\text { Beliefs }\end{array}$} & $\begin{array}{l}0=\text { partisipan belum mengetahui } \\
\text { keterampilan yang diberikan }\end{array}$ & \multirow{4}{*}{$\begin{array}{l}\text { Jawaban } \\
\text { partisipan } \\
\text { terhadap } \\
\text { semua } \\
\text { Pertanyaan: } \\
\text { Khusus } 3 \text { \& } \\
\text { Observasi } \\
\text { Sesi } 3\end{array}$} \\
\hline & $\begin{array}{l}1=\text { Partisipan dapat mengingat } \\
\text { ketujuh tahap dalam berpikir } \\
\text { secara akurat }\end{array}$ & \\
\hline & $\begin{array}{lrr}2 \quad=\text { Partisipan } & \text { mampu } \\
\text { menguraikan dengan } & \text { kata-kata } \\
\text { sendiri bagaimana alur } & \text { berpikir } \\
\text { untuk menentukan } & \text { akar } \\
\text { permasalahan secara akurat } & \\
\end{array}$ & \\
\hline & $\begin{array}{l}3=\text { Partisipan mampu } \\
\text { menjelaskan pada situasi seperti } \\
\text { apa keterampilan ini bisa } \\
\text { digunakan dan menggunakannya } \\
\text { untuk menemukan akar dari } \\
\text { permasalahan yang dialaminya }\end{array}$ & \\
\hline \multirow{2}{*}{$\begin{array}{c}\text { Skill 4: } \\
\text { Putting It In } \\
\text { Perspectives }\end{array}$} & $\begin{array}{l}0=\text { partisipan belum mengetahui } \\
\text { keterampilan yang diberikan }\end{array}$ & \multirow{2}{*}{$\begin{array}{l}\text { Jawaban } \\
\text { partisipan } \\
\text { terhadap } \\
\text { semua } \\
\text { Pertanyaan: }\end{array}$} \\
\hline & $\begin{array}{l}1=\text { Partisipan dapat mengingat } \\
\text { kelima tahap untuk memprediksi } \\
\text { output secara realistis }\end{array}$ & \\
\hline
\end{tabular}

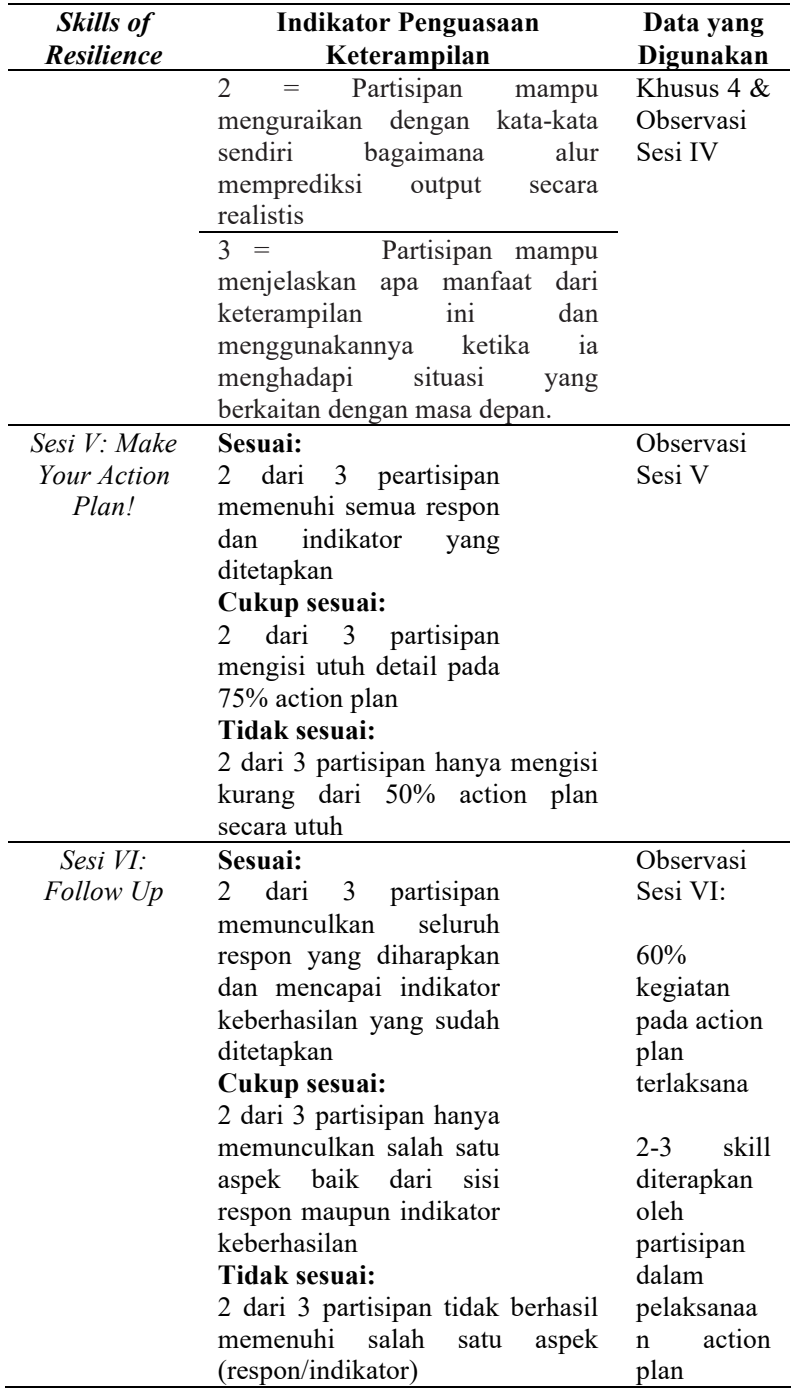

\section{HASIL DAN PEMBAHASAN}

\section{Hasil Analisis Kuantitatif}

Berikut adalah hasil analisis statistik menggunakan uji tanda Wilcoxon:

Tabel 3. Hasil Uji Statistik Wilcoxon

\begin{tabular}{lc}
\hline \multicolumn{1}{c}{ Faktor Resiliensi } & .sig \\
\cline { 2 - 2 } Impuls Control & $0,047^{*}$ \\
Causal Analysis & 0,109 \\
Realistic Optimism & 0,285 \\
\hline *signifikan untuk nilai $p=0,05$ &
\end{tabular}

\section{Hasil Analisis Kualitatif}

Berikut adalah hasil analisis kualitatif dengan membandingkan kondisi sebelum dan setelah coaching berdasarkan alat ukur observasi dan wawancara: 
Tabel 4. Hasil Analisis Kualitatif

\begin{tabular}{|c|c|c|c|c|}
\hline Parti & pan & Pra & Post & Bukti Utama \\
\hline \multirow{3}{*}{$\begin{array}{l}\text { Skill1: } \\
\text { Learning } \\
\text { Your } \\
\text { ABC }\end{array}$} & $\mathrm{P}$ & 0 & 1 & $\begin{array}{l}\text { P menyatakan 'lupa'. Dapat } \\
\text { menyebutkan kembali seperti apa } \\
\text { itu ABC ketika peneliti mengajak P } \\
\text { untuk mengingat pertemuan } \\
\text { sebelumnya. }\end{array}$ \\
\hline & M & 0 & 3 & $\begin{array}{l}\text { M dapat menguraikan masalah yang } \\
\text { terjadi pada saat menjalankan action } \\
\text { plan. Ia dapat menyebutkan apa } \\
\text { belief dan konsekuensi dari masalah } \\
\text { yang dia alami tersebut. }\end{array}$ \\
\hline & $\mathrm{D}$ & 0 & 3 & $\begin{array}{l}\text { D dapat menguraikan masalah yang } \\
\text { terjadi pada saat menjalankan action } \\
\text { plan. Ia dapat menyebutkan apa } \\
\text { belief dan konsekuensi dari masalah } \\
\text { yang dia alami tersebut. }\end{array}$ \\
\hline \multirow{3}{*}{$\begin{array}{l}\text { Skill2: } \\
\text { Avoiding } \\
\text { Thinking } \\
\text { Traps }\end{array}$} & $P$ & 0 & 3 & $\begin{array}{l}\text { Dapat langsung menyebutkan inti } \\
\text { dari skill yaitu 'harus melawan } \\
\text { pikiran negatif dengan positive } \\
\text { thinking'. } \mathrm{P} \text { memegang teguh } \\
\text { belief nya (jawaban dari self- } \\
\text { question) untuk mengatasi } \\
\text { hambatan yang muncul dalam } \\
\text { melaksanakan action plan. }\end{array}$ \\
\hline & M & 0 & 3 & $\begin{array}{l}\text { M pun mampu memanfaatkan } \\
\text { keterampilan ini ketika pemikiran } \\
\text { negatif muncul pada saat ujian dan } \\
\text { pada saat ia malas belajar }\end{array}$ \\
\hline & $\mathrm{D}$ & 0 & 3 & $\begin{array}{l}\text { Pada saat mengahdapi ujian, D } \\
\text { berusaha melakuakn self- } \\
\text { questioning untuk menghalau } \\
\text { pemikiran negatif yang muncul }\end{array}$ \\
\hline \multirow{3}{*}{$\begin{array}{l}\text { Skill3: } \\
\text { Challengi } \\
n g \text { Beliefs }\end{array}$} & $\mathrm{P}$ & 0 & 1 & $\begin{array}{l}\text { Sama sekali tidak bisa mengingat } \\
\text { proses untuk berpikir secara akurat } \\
\text { sehingga peneliti harus } \\
\text { menjelaskannya kembali }\end{array}$ \\
\hline & M & 0 & 2 & $\begin{array}{l}\text { M sebenarnya mampu } \\
\text { mengaplikasikan keterampilan } \\
\text { challenging belief, untuk berpikir } \\
\text { secara akurat, namun pada aspek } \\
\text { organisasional. Untuk area } \\
\text { akademik, M merasa belum bisa } \\
\text { menemukan kapan dia harus } \\
\text { menerapkan keterampilan ini. }\end{array}$ \\
\hline & $\mathrm{D}$ & 0 & 1 & $\begin{array}{l}\text { D mengakui dia belum memahami } \\
\text { maksud dari sesi yang melatihkan } \\
\text { keterampilan ini }\end{array}$ \\
\hline \multirow{3}{*}{$\begin{array}{l}\text { Skill4: } \\
\text { Putting It } \\
\quad \text { In } \\
\text { Perspecti } \\
\quad \text { ves }\end{array}$} & $\mathrm{P}$ & 0 & 1 & $\begin{array}{l}\text { Cenderung optimis namun tidak } \\
\text { bisa menjelaskan alasan nyatanya }\end{array}$ \\
\hline & $\mathrm{M}$ & 0 & 1 & $\begin{array}{l}\text { Cenderung pesimis (sama seperti } \\
\text { sebelum pendampingan) }\end{array}$ \\
\hline & D & 0 & 1 & $\begin{array}{l}\text { Cenderung pesimis (sama seperti } \\
\text { sebeum pendampingan) }\end{array}$ \\
\hline \multirow{3}{*}{$\begin{array}{l}\text { Sesi V: } \\
\text { Make } \\
\text { Your } \\
\text { Action } \\
\text { Plan! }\end{array}$} & $\mathrm{P}$ & \multicolumn{2}{|c|}{ Sesuai } & $\begin{array}{l}\text { Peneliti: } \\
\text { Terpenuhi } \\
\text { Rater 1: } \\
\text { Terpenuhi } \\
\text { Rater 2: } \\
\text { Terpenuhi }\end{array}$ \\
\hline & M & \multicolumn{2}{|c|}{ Sesuai } & $\begin{array}{l}\text { Peneliti: } \\
\text { Terpenuhi } \\
\text { Rater 1: } \\
\text { Terpenuhi } \\
\text { Rater 2: } \\
\text { Terpenuhi }\end{array}$ \\
\hline & $\mathrm{D}$ & \multicolumn{2}{|c|}{ Sesuai } & $\begin{array}{l}\text { Peneliti: } \\
\text { Terpenuhi } \\
\text { Rater 1: }\end{array}$ \\
\hline
\end{tabular}

\begin{tabular}{|c|c|c|c|}
\hline \multicolumn{2}{|c|}{ Partisipan } & Post & Bukti Utama \\
\hline & & & $\begin{array}{l}\text { Terpenuhi } \\
\text { Rater 2: } \\
\text { Terpenuhi }\end{array}$ \\
\hline \multirow{3}{*}{$\begin{array}{c}\text { Sesi VI: } \\
\text { Follow } \\
\text { Up }\end{array}$} & $\mathrm{P}$ & Tidak Sesuai & $\begin{array}{l}\text { Peneliti: } \\
\text { Tidak tercapai } \\
\text { Rater 1: } \\
\text { Tidak tercapai } \\
\text { Rater 2: } \\
\text { Tidak tercapai }\end{array}$ \\
\hline & M & Cukup Sesuai & $\begin{array}{l}\text { Peneliti: } \\
\text { Tercapai } 1 \text { dari } 2 \text { indikator } \\
\text { Rater 1: } \\
\text { Tercapai } 1 \text { dari } 2 \text { indikator } \\
\text { Rater 2: } \\
\text { Tercapai } 1 \text { dari } 2 \text { indikator }\end{array}$ \\
\hline & $\mathrm{D}$ & Sesuai & $\begin{array}{l}\text { Peneliti: } \\
\text { Tercapai } \\
\text { Rater 1: } \\
\text { Tercapai } \\
\text { Rater 2: } \\
\text { Tercapai }\end{array}$ \\
\hline
\end{tabular}

\section{Dinamika Penguasaan Learning Your ABC skill \& Avoiding Thinking Traps skill sebagai Sarana Pengembangan Faktor Impuls Control}

Proses pertama yang harus dihayati oleh partisipan untuk dapat menguasai keterampilan pertama adalah menyadari adanya automatic thought yang muncul pada saat individu dihadapkan pada suatu kejadian. Automatic thought pada pendampingan ini disebut sebagai belief. Peneliti memberikan psikoedukasi mengenai $\mathrm{ABC}-$ Adversity, Beliefs, Consequences. Peneliti menjelaskan maksud dari $\mathrm{ABC}$ dan bagaimana ketiga aspek ini saling mempengaruhi. Kemudian peneliti memberikan $A B C$ Activity sheet untuk membantu partisipan mengidentifikasi $\mathrm{ABC}$ sekaligus menghayati bagaimana hubungan antar ketiga aspek tersebut (yang merupakan proses kedua dan ketiga yang harus dilalui untuk menguasai keterampilan Learning Your ABC). Permasalahan sehari-hari yang sedang atau sering dialami menjadi sarana untuk mengidentifikasi $\mathrm{ABC}$ tersebut.

Pada saat psikoedukasi, terlihat bahwa $\mathrm{ABC}$ adalah suatu materi yang baru bagi mereka (beberapa kali partisipan bergumam "oooh../ jadi gitu ya.../ hmm" - sambil mengangguk-angguk). Pada pengisian worksheet, partisipan dapat mengikuti apa yang diinstruksikan peneliti dengan baik. Partisipan pada awalnya harus dipandu satu per satu untuk mengidentifikasi ABC. Seiring dengan bertambahnya permasalahan yang dibahas, partisipan hanya perlu dipandu oleh peneliti dengan 2 kali pertanyaan (hasil ada pada tabel 4). Pada akhir sesi pertama, partisipan mengungkapkan bahwa ternyata ada struktur yang sebaiknya diidentifikasi ketika sedang mengalami situasi sulit maupun menantang. Partisipan pun 
menyebutkan bahwa belief lah yang paling penting dalam menentukan tingkah laku apa yang akan terjadi dan memang paling sulit untuk diidentifikasi. Pada saat sesi follow up, jika peneliti bertanya 'belief apa yang muncul pada saat hal itu terjadi?', $M$ dan D dapat langsung menjelaskan belief-nya tanpa tercampur dengan konsekuensi. Sedangkan P sampai pada sesi follow up masih membutuhkan banyak bantuan dari peneliti untuk sampai akhirnya dapat menentukan belief.

Berdasarkan uraian di atas, semua partisipan menyadari adanya belief. Tidak hanya itu, partisipan pun memahami bagaimana keterkaitan dari $\mathrm{ABC}$ ditandai dengan penyataan bahwa belief adalah aspek yang paling penting dalam menentukan tingkah laku dan emosi apa yang dirasakan saat situasi sulit terjadi. Identifikasi $\mathrm{ABC}$ pun dapat dilakukan terbukti dari tercapainya indikator keberhasilan pada tabel 4. Peneliti pun menemukan bahwa semakin banyak permasalahan yang dibahas untuk diidentifikasi ABC-nya, semakin mahir pula partisipan dalam melakukan keterampilan ini. Oleh karena itu, peneliti menyimpulkan bahwa rancangan ini sudah sesuai untuk melatihkan Skill 1: Learning Your $A B C$ dengan catatan ada penambahan jumlah permasalahan yang sebaiknya dibahas.

Proses berikutnya dilakukan dalam rangka untuk menguasai Skill 2: Avoiding Thinking Traps yaitu menguji belief dan memunculkan belief alternatif yang dapat menunjang produktivitas akademik partisipan. Untuk menguji belief, partisipan digugah untuk memunculkan self-question yang berhubungan dengan thinking traps yang menurutnya sering muncul. Peneliti meminta partisipan untuk menuliskan belief, tergolong pada thinking traps apa, dan self-question apa yang sebaiknya dimunculkan untuk memperanyakan ke-valid-an dari belief tersebut pada worksheet yang telah disediakan. Sebelum menggolongkan jenis thinking traps, peneliti memberikan psikoedukasi berupa 8 jenis thinking traps, contohnya, dan bertanya pada partisipan apakah mereka sudah pernah mengalami pemikiran yang serupa. Sebelum menentukan selfquestion pun peneliti mengajak partisipan berdiskusi mengenai pemikiran seperti apa yang harusnya dimunculkan oleh individu agar tidak terjebak ke dalam thinking traps. Untuk memfasilitasi kemunculan belief alternatif, peneliti bertanya pada partisipan apakah partisipan sudah menemukan jawaban dari setiap pertanyaan yang muncul atau belum. Jika sudah, itulah yang menjadi belief alternatif untuk melawan belief yang mendistraksi.

Pada saat penentuan thinking traps, partisipan terlihat memahami apa yang disampaikan peneliti. Partisipan memberikan minimal response (kadang mengangguk, tersenyum, tertawa kecil) ketika thinking traps yang dijelaskan pernah juga dialami oleh mereka. Semua partisipan dapat meyebutkan sendiri tergolong pada jenis thinking traps yang manakah belief mereka itu. Peneliti hanya mengkonfirmasi jawaban dari partisipan. Begitu pula pada saat pembuatan self-question. Partisipan dapat memunculkan sendiri sejumlah pertanyaan berdasarkan dengan apa yang telah didiskusikan sebelumnya (hasil ada pada tabel 4). Dua dari tiga partisipan pun mengakui sudah mendapatkan jawaban dari self-question yang mereka tulis dan paham bahwa kedua hal tersebut (Self-question dan jawabannya) lah yang dapat menghambat impulsive atau negative belief.

Berdasarkan respon partisipan terhadap aktivitas pendampingan yang peneliti berikan, terlihat bahwa partisipan telah menagalami dan dapat melakukan secara mandiri proses untuk menguji ketepatan belief dan upaya untuk membentuk belief alternatif. Proses yang harus diperkuat adalah dalam pembentukan belief alternatif dengan cara memastikan setiap partisipan bisa menemukan dan akan menemukan jawaban dari self-question yang mereka tuliskan. Oleh karena itu, peneliti menyimpulkan bahwa rancangan ini sudah sesuai untuk melatihkan Skill 2: Avoiding thinking Traps dengan catatan diberikan aktivitas tambahan untuk menemukan jawaban dari self-question yang telah dituliskan.

Berdasarkan proses yang terjadi pada partisipan, berhasilnya setiap partisipan dalam menguasai keterampilan Learning Your ABC dan Avoiding Thinking Traps, terlihat bahwa terdapat perubahan tingkah laku yang berkaitan dengan impuls control. Sebelum pendampingan, ketiga partisipan cenderung mengikuti impulsive belief nya secara langsung. Namun setelah pendampingan, partisipan terlihat berupaya untuk menangkisnya dengan belief yang merupakan jawaban dari self-question yang telah mereka buat (tabel 4). Hal ini menandakan partisipan telah mengupayakan dirinya untuk mengaplikasikan keterampilan kedua ini. Faktor impuls control bukan berarti tidak mengalami perubahan berupa peningkatan (seperti yang tertera pada tabel 4) melainkan faktor ini belum akan meningkat dalam waktu yang relatif singkat. Dibutuhkan sejumlah pengalaman tambahan untuk membiasakan partisipan dalam mengaplikasikan tiap keterampilan ini dalam kehidupan sehari-harinya

\section{Dinamika Penguasaan Learning Your ABC skill \& Challenging Beliefs skill sebagai Sarana Pengembangan Faktor Causal Analysis}

Proses pertama yang harus dihayati oleh partisipan untuk dapat menguasai keterampilan challenging belief adalah menyadari bagaimana cara berpikir mereka dan apa konsekuensinya pada saat mereka menemui permasalahan. Partisipan pun perlu 
menyadari perlunya pengembangan cara berpikir mereka agar lebih resilien dalam menghadapi masalah. Setelah proses di atas dilalui, peneliti akan membantu pengembangan cara berpikir mereka dengan cara memperkenalkan cara berpikir yang runut dalam menentukan akar permasalahan secara akurat. Melalui worksheet yang peneliti sediakan, ada 7(tujuh) tahap yang partisipan lalui untuk menemukan akar permasalahan secara akurat.

Pada tahap pertama, partisipan diminta untuk mengidentifikasi kembali ABC dari permasalahan yang mereka bahas. Pada tahap ini, hanya D-lah yang mampu mengisi lembar ABC secara lengkap sedangkan dua partisipan lainnya tidak mengisi lembar tersebut dan hanya menyebutkan permasalahan apa yang akan dibahas. Hal ini terjadi karena peneliti sendiri tidak memberikan lembar ABC itu pada partisipan. Tahap kedua, partisipan diminta untuk mengidentifikasi why belief - yaitu belief yang menyebabkan permasalahan itu terjadi. Partisipan diminta untuk menuliskan, menentukan persentase kontribusi dari setiap why belief, dan menentukan apakah belief itu bisa diubah atau tidak. Peneliti harus memandu partisipan dalam menentukan why belief dengan cara mengajukan beberapa pertanyaan yang menjadi kemungkinan berbagai penyebab permasalahan yang mungkin muncul. Setelah itu, partisipan dapat melakukannya secara mandiri. Tahap ketiga, partisipan diminta untuk menentukan explanatory style dari setiap why belief yang ada. Sebelumnya peneliti harus memberikan 2 (dua) buah contoh penentuan explanatory style baru partisipan bisa menentukan sendiri.

Tahap keempat adalah menentukan belief alternatif yang berbeda jenis explanatory style nya dengan belief yang pertama. Tahap inilah yang menurut peneliti paling sulit untuk dipahami oleh partisipan. Peneliti harus memberikan lebih dari dua contoh dan pada satu partisipan bahkan menggunakan belief yang dimunculkan oleh partisipan. Meskipun memakan waktu yang paling lama, partisipan tetap dapat mengisinya. Pada akhirnya partisipan dapat memunculkan belief yang variatif dalam menghadapi permasalahan itu.

Tahap kelima, partisipan diminta untuk mengumpulkan bukti yang mendukung maupun menolak semua belief yang ada. Peneliti memberikan contoh sebanyak dua kali dan kemudian partisipan dapat menjawabnya sendiri. Setelah penulisan bukti, peneliti mengajak partisipan untuk mendiskusikan bukti mereka. Pada saat diskusi partisipan dapat mengemukakan pengalaman menjadi bukti pendukung maupun penolak belief yang sesuai.

Tahap keenam, partisipan diminta kembali mengisi lembar kerja yang sama dengan tahap kedua namun kali ini hanya mengisi dengan why belief yang menurut mereka menjadi akar permasalahan mereka. Pada 2 partisipan, peneliti harus mengarahkan mereka pada akar permasalahannya apa. Sedangkan 1 partisipan dapat dengan mantap menentukan sendiri akar permasalahannya. Tahap ketujuh partisipan diminta untuk menentukan solusi yang kongkrit untuk mengatasi why belief tersebut. Semua partisipan dapat melakukannya (hasil pada tabel 4).

Berdasarkan uraian proses dan respon partisipan di atas, terlihat bahwa terdapat proses yang terlewat, tidak dilatihkan oleh peneliti yaitu proses identifikasi konsekuensi dari cara berpikirnya serta menggugah kesadaran partisipan akan pentingnya pengembangan cara berpikir dalam menghadapi permasalahan. Hal ini menyebabkan proses yang diberikan oleh peneliti hanyalah pemberian pengalaman tanpa partisipan tahu apa makna dari pengalaman tersebut. Secara pengalaman di tiap tahapnya, rancangan sudah dibuat dengan sesuai (dapat memfasilitasi penyampaian tiap tahap). Namun rancangan ini belum cukup sampai partisipan menyadari perlu adanya pengembangan cara berpikir yaitu dengan cara memahami proses berpikir akurat ini. Hal ini lah yang membuat rancangan sesi ini dinyatakan cukup sesuai. Ada halhal yang harus dikembangkan yaitu aktivitas untuk memfasilitasi proses kedua sampai ketiga dan memperbanyak pembahasan permasalahan.

Oleh karena itu, wajar jika peneliti tidak dapat menemukan indikasi adanya perubahan positif pada tingkah laku yang terkait faktor Causal Analysis. Wajar pula jika tidak terjadi peningkatan pada faktor causal analysis (tabel 4). Partisipan belum bisa memahami alur berpikir secara akurat berikut makna dari pemberian pengalaman pada sesi keterampilan ketiga ini

\section{Dinamika Penguasaan Putting It In Perspective skill sebagai Sarana Pengembangan Faktor Realistic Optimsm}

Putting It In Perspectives skill adalah keterampilan yang digunakan untuk meningkatkan faktor Realistic Optimism pada partisipan. Untuk menguasai keterampilan ini, partisipan diajak setahap demi setahap untuk berpikir mengenai apa yang akan terjadi dan output apa yang akan mereka dapatkan secara lebih realistis. Pada intinya, partisipan akan selalu diajak untuk mengumpulkan bukti yang mendukung maupun melawan dari negative cognitive triad yang selalu muncul pada diri mereka. Bukti itu dikumpulkan setahap demi setahap, dimulai dari identifikasi situasi terburuk, identifkasi kemungkinan terbaik, sampai identifikasi output yang paling mungkin terjadi.

P memiliki belief yang sangat kuat untuk harus berpikir positif di segala situasi. Hal ini cukup menghambat peneliti dalam melatihkan putting it in 
perspective skill. $\mathrm{P}$ terlihat menolak untuk memikirkan dampak negatif yang akan terjadi. Ketika peneliti meminta $\mathrm{P}$ untuk mengumpulkan data yang menunjang prediksi output-nya, P hanya berkata 'insya Allah bisa kok, kak!' secara berulang. Dalam hal ini, P menunjukkan sikap yang optimis namun tidak realistis. Gagalnya peneliti dalam menggugah $P$ untuk mengikuti tahap keterampilan memprediksi secara realistis membuat $\mathrm{P}$ kurang bisa menangkap maksud dari keterampilan tersebut.

Faktor realistic optimism yang cenderung rendah tercermin pada kesulitan $M$ untuk memprediksi output yang akan terjadi terutama dalam bidang akademik. Dalam proses melatihkan putting it in perspective skill, $\mathrm{M}$ dapat mengutarakan berbagai dampak positif dan negatif yang mungkin terjadi. Pada saat $\mathrm{M}$ diminta untuk menjelaskan apa data dari kemungkinan yang paling mungkin terjadi, $M$ menghitung SKS dan berapa huruf mutu B yang bisa ia dapatkan untuk mencapai hal tersebut. Kemudian solusinya ia tuangkan ke dalam action plan. Pada sesi follow up, M menyadari bahwa banyak kegiatan yang tidak berjalan sesuai rencana. Hal ini membuatnya mempertimbangkan kembali beberapa output yang bisa ia capai dan berdampak pada tidak percaya diri M untuk bisa mencapai IPK yang diharapkan. Meskipun $M$ berupaya untuk realistis, $M$ kurang berhasil membawa dirinya untuk tetap optimis.

Faktor realistic optimism yang cenderung rendah tercermin pada kesulitan D untuk memprediksi output yang akan terjadi terutama dalam bidang akademik. D berupaya untuk mengikuti tahapan yang disampaikan oleh peneliti namun ternyata tidak membantunya untuk bisa memahami bagaimana cara untuk memprediksi output dengan realistis. Dampaknya, ia tetap ragu untuk menentukan output yang akan datang. D khawatir jika dia memprediksi dan itu ketinggian, D akan sangat kecewa. D pun tetap kurang optimis dalam menghadapi situasi yang akan datang.

Pada sesi follow up terlihat bahwa tidak terjadi perubahan pada tingkah laku partisipan yang terkait dengan realistic optimism. $\mathrm{P}$ masih tetap terlalu optimis sedangkan $\mathrm{M}$ dan $\mathrm{D}$ masih menunjukkan adanya ketidakpercayaan diri. Ketiga partisipan belum bisa menjelaskan bagaimana cara memprediksi output secara realistis namun tetap optimis. Pada akhirnya proses yang seharusnya terjadi tidak berjalan seharusnya dikarenakan ada halangan dari pengalaman partisipan mengenai output akademik yang selama ini dialaminya.

Hal ini dapat disebabkan karena beberapa situasi yaitu (1) keterampilan ini dilatihkan pada hari kedua setelah challenging belief dilakukan. Melatih keterampilan challenging belief sendiri menyita sebagian besar waktu yang tersedia sehingga partisipan mulai lelah ketika memasuki keterampilan yang terakhir; (2) peneliti belum mengadaptasi rancangan yang sesuai dengan karakteristik partisipan, termasuk di dalamnya sistem akademik yang mereka lalui

\section{SIMPULAN}

Rancangan pendampingan 4 skills of resilience ini belum sesuai untuk bisa meningkatkan keseluruhan kemampuan resiliensi mahasiswa bidik misi dengan profil cenderung rendah pada faktor impuls control, causal analysis, dan realistic optimism. Peningkatan faktor resiliensi terjadi pada faktor Impuls Control yang difasilitasi oleh keterampilan Learning your ABC's dan Avoiding Thinking Traps (Sesi I dan II). Peningkatan yang terjadi ternyata hanya pada tingkat pemahaman partisipan. Pendampingan yang dirancang sebanyak 6 sesi ini belum memadai untuk mencapai level applying pada partisipan. Ketika partisipan belum dapat mengaplikasikan keempat keterampilan ini maka kemampuan resiliensi pun diprediksi tidak akan meningkat. Aspek utama yang harus diperbaiki adalah dari segi waktu, penekanan pada pemanfaatan keterampilan, dan latihan untuk memanfaatkan keempat keterampilan tersebut.

\section{DAFTAR PUSTAKA}

Calaguas, G. M. (2012). Teacher effectiveness scale in higher education: Development and psychometric properties. International Journal of Research Studies in Education, 1(1), 118.Cresswell, J. W. (2003). Research design: qualitative and mixed-method approaches.

Cresswell, M. J. (2007). Language in the world: a philosophical enquiry. Cambridge University Press.

Gillham, J. E., Reivich, K. J., Freres, D. R., Chaplin, T. M., Shatté, A. J., Samuels, B., ... \& Seligman, M. E. (2007). School-based prevention of depressive symptoms: A randomized controlled study of the effectiveness and specificity of the penn resiliency program. Journal of Consulting and Clinical Psychology, 75(1), 9.

Goodwin, A. L. (2002). Teacher preparation and the education of immigrant children. Education and urban society, 34(2), 156-172.

Hussain, A., Kumar, A., \& Husain, A. (2008). Academic stres and adjustment among high school students. Journal of the Indian academy of Applied Psychology, 34(9), 70-73. 
Martin, A. J., \& Marsh, H. W. (2003). Fear of failure: Friend or foe?. Australian Psychologist, 38(1), 31-38.

Masten, A. S. (2015). Ordinary magic: Resilience in development. Guilford Publications.

Pearson, J., \& Hall, D. K. (2006). Reaching In-Reaching Out: Resiliency Guidebook:" bounce Back" Thinking Skills for Children and Adults. Child \& Family Partnership.

Reivich, K., \& Shatté, A. (2002). The resilience factor: 7 essential skills for overcoming life's inevitable obstacles. Broadway Books.

Reivich, K. J., Seligman, M. E., \& McBride, S. (2011). Master resilience training in the US Army. American Psychologist, 66(1), 25.

Robotham, D. (2008). Stres among higher education students: towards a research agenda. Higher education, 56(6), 735-746.

Siegel, S. (1956). Nonparametric statistics for the behavioral sciences.

Sudjana, N. (2005). Metode statistika. Bandung: Tarsito, 168.

Sugiyono, M. P. P. (2009). Pendekatan kualitatif. Kuantitatif dan R\&D, Jakarta: Alfabeta.

Waxman, H. C., Gray, J. P., \& Padron, Y. N. (2003). Review of research on educational resilience. 